\title{
Overcoming Ontological Alienation in the Urban Environment
}

\author{
Olga M. Farkhidinova* and Valeriia A. Shumkova \\ Ural Federal University \\ named after the First President of Russia B.N. Yeltsin \\ 51 Lenina, Ekaterinburg, 620083, Russia
}

Received 08.11.2018, received in revised form 24.04.2019, accepted 06.05.2019

In order to improve the conceptual apparatus of epistemology, it is important not only to accumulate variations in thought experiments, to use them for clarifying the key points of reference theory and the degree of ontological assumptions made together with the language usage, but also to question the appeal of explanatory properties of empirical methods for the development of knowledge about the mental states of the "other Self". This article is divided into two parts: the first one is a theoretical substantiation of the change in the focus of understanding religious experience problem; the second one centres around an example that demonstrates the need to address thought experiments at the stage of identification of human experiences, called religious, since only these experiences grant the opportunity to "expand our own reflexive understanding of the features of our own conceptual scheme" (Stroson, 2009: 97).

Keywords: identity, public religiosity, religious experience, experiences, heuristic value of thought experiments.

Research area: philosophy.

Citation: Farkhidinova, O.M., Shumkova, V.A. (2019). Overcoming ontological alienation in the urban environment. J. Sib. Fed. Univ. Humanit. soc. sci., 12(5), 771-779. DOI: 10.17516/1997-1370-0423.

One of the most productive ways of organizing scientific knowledge in the history of European science was a thought experiment. Its role has been significantly revised in the $21^{\text {st }}$ century. It was this type of experiment which gave, in addition to the hope for an increment of scientific knowledge, conceivable independence from practical verification, from the need to reconcile what is cogitable with actuality embodied in reality. In two cases this independence can be transformed by a research interest: when

(C) Siberian Federal University. All rights reserved

* Corresponding author E-mail address: ofarhetdin@mail.ru

ORCID: 0000-0001-8459-071 (Farkhidinova); 0000-0001-8382-9436 (Shumkova)

This work is licensed under a Creative Commons Attribution-NonCommercial 4.0 International License (CC BY-NC 4.0). 
the researcher makes a statement about the reality of a person's mental experiences (concerning the past); and also when the researcher extrapolates the meaning of these experiences into the design of the future (about the future). The validity of both cases is determined by the boundaries in which the ontological alienation of a person occurs.

In the $20^{\text {th }}$ century, within the framework of the analytical tradition in philosophy, the emphasis was placed on a thorough analysis of specific problems and the degree of reasoning in the proposed versions of how to treat these problems. In this respect, there shall be applied conventionally indicative thought experiments, which are different from the thought experiments well-known in the history of philosophy, such as the "statue" of Condillac. These thought experiments are the following: Wittgenstein's "beetle”, Quine’s "gavagai", Strawson's “sound world”, Jackson's "Mary the superscientist", etc. A significant advantage of mental experiments, since the introduction of this concept into the philosophy of science by E. Mach, has been that the clarification of "instinctive knowledge", according to E. Mach, is initiated by extreme situations of a mental experiment.

In the modern city, much is perceived differently, including that how the way of the relationship with the sacred is interpreted. What people have always talked about (their religious experience) sometimes cannot be voiced in the language of "collective thinking"; it cannot be defined in the semantic field of everyday life, and be written in the context of social consciousness. The very publicity of ways of organizing relationships with the sacred in the modern urban environment is one of the factors influencing mental states.

Materialization and objectification of the risk of belief in overcoming ontological alienation in the conditions of the urban environment has several features. In fact, today the cities described in the metaphors of communities are a current sociological project, which leaves no room for existential being. Most urban researches are aimed at justifying a heuristically limited idea of the urban environment as an organism. For reaching the goals of this article, we are interested in the city in the metaphors of the creation of human relations with the sacred. In this case, these relations do not embrace popular culture, but instead - the possibility and need of a person to express their attitude to the sacred in "public". Consequently, religiosity, which in this case arises, can be called public.

The starting point was two concepts: "public" and "publicity", understood as the most popular ways of organizing communication with the sacred in the city space. The following questions were formulated as additional ones: How can the religiousness of 
urban space be studied? What tools does a sociologist of religion have for this? What are the possibilities of a philosopher of religion? Has the organization of communication/ relation with the sacred changed in a space defined as public?

In the stated problem field, there is a lack of research. In exceptional cases, we can distinguish the formation of the ability to express one's religiosity in the presence of an observer. One of the successful attempts to name this ability was the project of Gabriel Tard, in which the term "public" received its present sense.

To illustrate the specifics of the situation indicated, let us turn to one of the examples. In 1919, Geddes received an order to create a university project and plan the construction of Jerusalem and Tel Aviv settlement. In his report "Jerusalem real and possible" he made a fundamental conclusion: social customs and religious ideas must be harmonized with modern reconstruction. As for social customs, they as a separate phenomenon are actively studied within the framework of a sociological approach. At the same time, the way how religion and the religious ideas in the modern city are represented needs to be clarified. Religion, which is "watched", is also projected as a museum religion. This uniquely contributes to the growing distance between what a person does and the one who observes this process of doing. Religion is perceived as an action for the viewer, hence appears its entourage and marketability. In this case, it becomes reasonable that if there is a viewer, there is something to sell.

So, religion is "perceived", and this is the main condition for the birth of a new ontology. The appearance of ontology, ontological substantiation for the reality of any event or a phenomenon is possible only when we have stable coordinates. One of the important coordinates of our time is that religion has an observer, and it is observed by those who exempt themselves from the limits of the need to follow all the rules by which religion exists in society. In the perceived religion, the relation "work viewer" is more important and more fundamental than the relation "author - work". Postmodern poetics shifted the emphasis from the process of production (making the work) to the process of reading and interpretation; with regard to religiosity it can be stated that there is something to read on the matter. There is a context fixing the condition for the existence of such religiosity. Knowledge necessarily involves an individual understanding. $<\ldots>$ The criterion of the justification of ideas and ideals of a person is the completeness of the opening up and learning about living space and the degree of satisfaction with this learning (Pivovarov, 2014: 69).

This way the main question changes for the following: whether laid up religiosity (museum religiosity which is looked at) is a consequence of its loss or preservation. 
Is it possible to distinguish religiosity in the space of the metropolis? Will religiosity maintain its attitude to religion? Whether acts of sacralisation on the part of the public (multitudes in relation to the spiritual connection) are a condition for denoting the break (the loss) of connection between existence and its less profound entities (ontic alienation)? Is it a new type of religiosity which evolves?

As soon as history begins to be broadcast through the actions of living people, religious ideas are transformed into stories "about religious experience". In the story of faith, the ontological alienation arising here is supported by all probable variants of questioning: how to believe? what to do? how to worship the subject of faith?

In the $20^{\text {th }}$ century, it became clear that in modern society one often lacks language to indicate what is experienced. While living in stress, a person is looking for effective ways to get out of it, or this person is guided by how others do this. Academic studies of the city are widely spread and applied today. An indicative example in this case is the experience of the Chicago School of Sociology. Acknowledging the importance of research aimed at studying human behaviour in urban environment, which was initiated by Robert Ezra Park, Everett Cherrington Hughes conducted studies in the field of professional sociology. The approach of R.E. Park, who learned philosophy at Harvard and assimilated the experience of such eminent professionals as W. James, J. Royce, G. Santayana, is of the greatest interest. In his dissertation entitled "Crowd and Public: A methodological and sociological study" it was precisely the question of the limited applicability of terminology to the new phenomena that was put: what are public ways of organizing communication with the sacred? As Gabriel Tard remarks, the modern age is the era of the public (mass) or masses, but not the crowds. The public is a spiritual aggregate of individuals, connected mentally.

Being studied by sociologists, the city and urbanization are given through the intuition of alienation and dissociation. The city is trying to compensate for the breakdown of integrity. The Chicago school (see, for example, the works of L. Wirth) brought into the context of our understanding the set of terms which describe distancing individuals from each other, for instance, these include: metaphor, community, communication.

Multitude of people and territories, previously described through a prism "here and there", today needs to be supplemented, as there are strangers "here" and there is also the problem of the "we-there" diaspora. The problem is further complicated by the fact that when a city code is being created in the language of the community, this leads to conflicts at various levels. The possibilities arising against the backdrop of studying religious experience are illustrative in this regard. 
In traditional societies, the individual's religiosity and identity were determined by the dominant religious discourse. The current period of the late modern epoch is marked by a decline in the authority of religious institutions, by pluralism, information accessibility, etc. In view of these tendencies, the religious experience of an individual who is at odds with religious tradition is characterized primarily by eclecticism and individualism.

In different contexts, be it everyday communication or academic research, we mostly deal directly not with experience-feeling, but with its linguistic representation. At the same time, the most common ways of representing experience are narratives or stories that shape this experience, establishing a sequence of events that are significant to the narrator and the audience.

In studies of narratives, there are two main approaches: constructivism and constructionism, which, despite their names, are fundamentally different in their philosophical and methodological attitudes to their object. The first approach is individualistic, so the narrative is conceptualized as a cognitive structure or process. In other words, it is an internalized form, the psychic function of the individual, which enables the organization and representation of experience, world, identity and others. On the contrary, in the constructionist approach the narrative is understood as a sociocultural phenomenon. This is not just a passive resource, a set of patterns that is used in the creation and interpretation of personal stories. Narratives are active: they order life events, bringing to the light some of them and hiding others; they thereby form experience and assign it some meaning. The meaning of a single life ultimately depends on how personal story resonates with a larger narrative.

Let us agree that the narrative is a broader concept in relation to story. This is any story containing an explanation of experience, a specific sequence of causes and effects, while story is a more specific genre, which presupposes the presence of such elements as actors, sequence of events, "complication", results, etc.

Summing it up, individuals use the spectrum of narratives available in a particular sociocultural context by constructing their own stories, representing themselves and reflecting on their experiences. Thus, one of the functions of narratives is the construction of "Self" and identity.

Narratives are rich empirical material for analysis. To demonstrate how the narrative about religious experience and the speaker's identity is constructed, we will focus on the following aspects. First of all, we shall outline the context, which is the general structure of narrative and the place of stories in it. Further, by taking an explicitly expressed religious self-identification as a starting point, we shall designate additional 
categories that reveal the content of self-identification: categories with which the respondent identifies or opposes / respondents identify or oppose themselves. We shall pay special attention to the attitude towards traditional religion and what resources (repertoires) the respondents address (besides or instead of religious concepts) in describing their experience.

The analyzed examples were selected from a series of semi-structured interviews conducted in 2017 among respondents aged 25-35 who believed that they had had a mystical experience. Let us examine two examples of narrative of people with different ideological worldviews and attitudes toward religion (tentatively and conventionally these were called "orthodox" and "non-confessional" believers). The interviews were structured in the form of narrative, in which the interviewee was endued with the leading role and the initiative. An initial question was a request to tell about a case connected with a mystical experience. Clarifying questions related to the prerequisites, the details of the consequences of this experience, as well as attitudes towards religion.

Example 1. In the first case, stories make up a large part of the narrative. The respondent (R1) told six stories that are linked by thematic associations. Stories embrace crisis family situations and "absolute events" (death, illness, quarrel, childbirth). The key episode, to which R1 returned several times, is associated with a major operation of a close relative. Cross-cutting issues are the efficacy of a prayer, faith as inner confidence in the outcome of events, communication with God, understanding of purpose and confluence of circumstances as the "response of the universe", perception of family traditions and rituals as methods of transmitting sacral knowledge.

The religious identity of $\mathrm{R} 1$ is formulated as follows: “...I can't say, for example, that I am a deeply religious practicing person. No, I have a very doubtful thinking, constant, that is, I believe that faith is alive". It is noteworthy that confessional affiliation is not mentioned (the respondent's attitude to Orthodoxy was known in advance). The emphasis in the narrative is placed on personal conscious faith, which develops from getting ritual experience and following family traditions into a special "inner knowledge" and personal relationship with God.

Religious, mystical experience becomes the central element of identity, a common feature of the group of like-minded people, “...who are looking for this sort of mystical experience, feeling this in life, that they sometimes hear or understand, they try to understand why they come to life". Religious experience as sacred knowledge is also coupled with the continuity of family traditions. 
There can be distinguished the following oppositions, by means of which the identity of the respondent can be created.

Religious experience as a special knowledge is opposed to the methods of evidencebased medicine, which focuses on symptoms and struggles for the life of the body, although it is the soul of man that matters.

Institutional religion is mentioned in a critical way: "when, you know, I came to church, I also say like, so, pray for my father, and they tell me the kind of whether we will read the last rites or not, is he baptized or not, I understood that as if religion's paradigm is no help to me at all".

Opposition to the abstract consumer society is the most pronounced one: "how deep is the difference between blind people $<\ldots .>$ even the dead, well, those who live as if reflexively in the consumption system, yeah in life, that is, they were born and died there and they put a dash between these dates and that's all, and there are people who are trying to live this life consciously".

In addition to Christian concepts (prayer, faith, church, soul, god, etc.), R1 uses words linked with spiritual practices: consciousness, co-attunement, energy, awareness, etc. Christian concepts are replaced by spiritual ones with the concomitant appearance of professional self-identification (yoga instructor). R1 also mentions philosophical education, and refers to such concepts as essence, sacred knowledge, "open knowledge according to Plato", etc. Thus, despite the postulation of her attitude to religion and religious tradition, the respondent uses Christian discourse as one of many repertoires or resources used in the description of personal experiences.

Example 2. In the second interview, the respondent (R2), following the request to tell about a specific case connected with a religious experience, conducts a peculiar analysis of his experience. R2 tries to structure the narrative summary according to some criteria (physical sensations, emotional side, "mental" or intellectual aspect of experiencing). There are only two stories in the narrative: the first is about the most intense feeling (the theme of a fight), the second is about the first experience in childhood (the theme of death and its rethinking).

Religious themes and self-identification emerge in the narrative rather on the initiative of the interviewer. R2 does not consider himself a religious person, explaining that there is no need for faith, because he knows that "there is something, that is, well, that is called a god". Formally, such a position can be called the position of a believer, however, the respondent himself opposes his worldview to a religious one. $\mathrm{R} 2$ cites the New Testament idea: "to believe is to do, that means, well, to realize 
what you <believe in>”; whereas religion, in his opinion, is reduced to dogmas and rituals.

Identity in the analyzed narrative is constructed primarily through the oppositions. Mystical experience is opposed to psychic deviations: "I have no voices, you know, so, no as if contacts there with some creatures, well, so, I am not apparently inclined to it, haw-haw, fortunately".

R2 compares his experiences with psychedelic experience: “... there is almost no difference between these states by and large. $<\ldots>$ this is also, well, altered state, in fact, it is caused by a, well, emotional certain mood $<\ldots>$ mental position, certain position". The respondent stresses that this is etiology of experience which is critical and makes up the difference between mystical and psychedelic experience.

In the most significant episode concerning the most intense feeling, the respondent opposes himself and his state of detachment to aggressiveness and lack of awareness on the part of a group of men.

In this example, the opposition to the society is also important: the described religious experience is viewed as a way of deep self-cognition and something which is connected with the essential aspect of personality. For the respondent, "Self" is not limited to social roles and relationships. To illustrate his point, the respondent suggests a puzzle metaphor: "you fall out of <...> this scheme. <..> It's like in puzzles, you know, these little things, protrusions and 'and such' such as if the hollows $<_{\ldots}>$ and they somehow smoothed out and you stop being a part of this puzzle that's comes to: you become just 'an item that doesn't seem to be applicable here at all <...> you cannot be controlled, it is impossible to demand anything from you, you cannot be intimidated, 'here', you cannot be bribed nor you can somehow be seduced by anything'.

In describing this experience, the respondent, despite the denial of his religiosity, recounts peculiar psychotechnics that he uses to get a mystical experience: reflections on Buddhist noble truths and Christian New Testament texts ("theme of love"), reading sutras, meditative techniques. The resources which the respondent uses are language of psychology and professional slang ("focus of attention", "altered space"), spiritualistic concepts ("physical body", "ocean of energy"), jargon ("scowl”, "be inadequate", "come up"," trip).

Thus, the considered examples make it possible to problematize the very concept of individual religiosity. In philosophical and psychological concepts (dating back to F. Schleiermacher, W. James), religious experience constitutes the religion's core and resource. For a modern person, a religious institution, tradition and individual 
experience turn out to be independently existing phenomena. Meanwhile, the institution is endowed with negative connotations; religious tradition is understood as a resource that can be used pragmatically, meeting someone's own needs. Mystical experience is not, in principle, considered in the context of religion and faith. When it is considered as an expression of a certain transcendental reality, this reality is contained in the individuals themselves.

\section{References}

Pivovarov, D.V. (2014). Nauka i Religia: gnoseologicheskie ocherki [Science and religion: epistemological essays]. Yekaterinburg, 344 p.

Stroson, P. (2009). Individuals. Experience of descriptive metaphysics. Kaliningrad, $260 \mathrm{p}$.

\section{Преодоление онтологического отчуждения в условиях городской среды}

О.М. Фархитдинова, В.А. Шумкова

Уральский федеральный университет им. первого Президента России Б. Н. Ельцина Россия, 620083, Екатеринбург, пр. Ленина, 51

С иелью совершенствования концептуального аппарата эпистемологии важно не просто накопить вариащии мысленных экспериментов, проясняя с их помощьюю ключевые положения теории референции и степень онтологических допущений, принимаемых вместе с языком, но и поставить под сомнение привлекательность объяснительных свойств эмпирических методов для развития знания о ментальных состояниях «другого Я». Статья разделена на две части: в первой рассматривается теоретическое обоснование изменения фокуса видения проблемы понимания религиозного опыта; во второй - анализируется пример, демонстрирующий необходимость обращения $\kappa$ мысленным экспериментам на этапе идентификации переживаний человека, именуемых религиозными, так как только с их помощью мы имеем возможность "расширить наше собственное рефлексивное представление об особенностях нашей собственной концептуальной схемы» (Stroson, 2009: 97).

Ключевые слова: идентичность, публичная религиозность, религиозный опыт, переживания, эвристическая иенность мысленных экспериментов.

Научная специиальность: 09.00.00 - философские науки. 